\title{
Factors influencing ultrasonic pulse velocity in concrete
}

\section{Fatores de influência na velocidade de pulso ultrassônico no concreto}
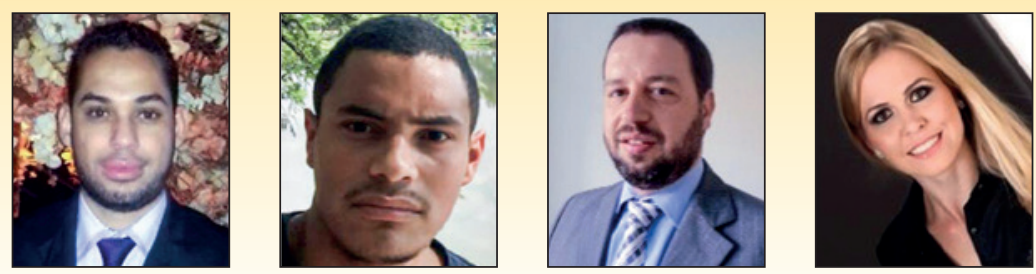

J. P. GODINHO a jayson.godinho.eng@gmail.com https://orcid.org/0000-0003-2948-8639

T. F. DE SOUZA JUNIOR ${ }^{\circ}$ tennisonufpr@outlook.com https://orcid.org/0000-0003-0235-3152

M. H. F. MEDEIROS a medeiros.ufpr@gmail.com https://orcid.org/0000-0003-3112-9715

M. S. A SILVA a https://orcid.org/0000-0001-5026-7676

\begin{abstract}
The hydration process of Portland cement triggers reactions of stabilization of minerals from the contact of the clinker with water, which is the Hydrated Calcium Silicate $(\mathrm{C}-\mathrm{S}-\mathrm{H})$, the Etringite $\left(3 \mathrm{CaO} \cdot \mathrm{Al}_{2} \mathrm{O}_{3} \cdot 3 \mathrm{CaSO}_{4} \cdot 32 \mathrm{H}_{2} \mathrm{O}\right)$ and the Portlandite $\left(\mathrm{Ca}(\mathrm{OH})_{2}\right)$. In order to understand the effects of the evolution of hydration in cement, it is possible to apply non-destructive tests. In this context, the objective of this work is to evaluate the influence of the type of cement, the curing age, of the format and humidity of the test specimens of concrete in the ultrasonic pulse velocity (UPV). In order to do that, 36 cylindrical test specimens $(10 \times 20 \mathrm{~cm})$ and 9 cubic ones with $25 \mathrm{~cm}$ of edges, with mix proportion of 1:2,7:3,2 (cement/sand/gravel), water/cement ratio of 0.58 and three types of Portland cement (CP II-Z-32, CP IV-32 RS and CP V-ARI) were molded. With data obtained it was possible to correlate the increase of concrete strength along time (at ages of 7, 14, 28, 70 and 91 days) with the increase of the ultrasonic pulse velocity. Besides, it was possible to prove the direct influence of the concrete moisture and of the degree of hydration in the UPV. The shape of the test specimen generally had no influence on the results, except in the case of cement CP V ARI.
\end{abstract}

Keywords: non-destructive testing, durability, water absorption.

\section{Resumo}

O processo de hidratação do cimento Portland desencadeia reações de estabilização de minerais provenientes do clínquer em contato com a água, que é o Silicato de Cálcio Hidratado $(\mathrm{C}-\mathrm{S}-\mathrm{H})$, a Etringita $\left(3 \mathrm{CaO} \cdot \mathrm{Al}_{2} \mathrm{O}_{3} \cdot 3 \mathrm{CaSO}_{4} \cdot 32 \mathrm{H}_{2} \mathrm{O}\right)$ e a Portlandita $\left(\mathrm{Ca}(\mathrm{OH})_{2}\right)$. Para o entendimento do efeito da evolução destes processos de hidratação, é possível aplicar o uso de ensaios não destrutivos. O objetivo do presente trabalho é avaliar a influência do tipo de cimento, da idade de cura, do formato e da umidade dos corpos de prova de concreto na velocidade de pulso ultrassônico (VPU). Para tal, foram moldados 36 corpos de prova cilíndricos $(10 \times 20 \mathrm{~cm})$ e 9 cúbicos com $25 \mathrm{~cm}$ de arestas, com traço 1:2,7:3,2 (cimento/areia/ brita), relação água/cimento de 0,58, e três tipos de cimento Portland (CP II-Z-32, CP IV-32 RS e CP V-ARI). Com os dados obtidos foi possível correlacionar o aumento da resistência do concreto ao longo do tempo (nas idades de 7, 14, 28, 70 e 91 dias) com o aumento da velocidade de pulso ultrassônico. Além disso, foi possível comprovar a influência direta da umidade do concreto e do grau de hidratação na VPU. A forma do corpo de prova, de modo geral não apresentou influência nos resultados, com exceção do caso do cimento CP V ARI.

Palavras-chave: ensaios não-destrutivos, durabilidade, absorção de água. 


\section{Introduction}

In reinforced concrete structures, the compressive strength of concrete consists in one of the most relevant and applied properties for dimensioning the structural elements. For evaluating this property in works, test specimens are molded and, posteriorly, broken in some healing ages under controlled conditions. Some authors cite that the hydration of Portland cement reaches, at 28 days of cure, near $70-80 \%$ of the degree of hydration and is practically completed at 365 days (Mehta e Monteiro [1]; Taylor [2]) . However, when the material is released, thickened and cured in the field, it will not be under the same conditions exposed in the tests and the effective degrees of hydration should be smaller than in cases of ideal cure conditions. The hydration process of cement may be directly evaluated using techniques such as microscopy, thermo-gravimetry or X-ray diffraction, or indirectly by determination of the heat developed in hydration (Naik et al. [3]; Neville [4]). But in structures molded "in loco" efficient alternatives are needed for evaluating concluded structures and in operating conditions, without damages to functionality or aspect (Pereira e Medeiros [5]).

In face of that, a usual method of inspecting and diagnosing the performance of structures is to extract, "in loco", the witness and to submit it to axial compression tests, in order to determine the compressive strength of the analyzed concrete. However, in many situations, the geometry of the structural element does not allow the standard obtention of the sample, besides affecting the stability of the piece (Castro et al. [6]).

For that, during the last decades, it was sought to develop new technologies enabling the exemption of damages or that would minimally interfere in the resistance capacity of the structure, also known as non-destructive tests. Besides allowing the monitoring and diagnosis of recent or old structures, the non-destructive tests should have interesting economic and operating characteristics, such as: easiness of operation, low operating cost of monitoring, speed of execution and, also, keeping unscathed the structure of the analyzed material, as reported by Grantham et al. [7]. Ultrasound is a representative of those non-destructive methods that, according to ASTM E 114 [8], may be used for detection of defects inside the concrete, as well as of deterioration due to the aggressiveness of the media and of ice-thaw cycles.

In functional terms, Ferrari and Padaratz [9] explained that when the mechanical impulses are applied to a solid, three waves are pro- duced, in a way that each wave allows a specific movement of particles, being them: Longitudinal (compression), transversal (crosscut) and superficial. Among the most varied factors (Example: presence of reinforcement, fissures, temperature and dimension of aggregate) there are factors intrinsic to the concrete that interfere in the measurements of the ultrasound testing such as type of cement, water/cement radio, hydration degree, and cure conditions of the concrete (NBR 8802 [10]; De Belie et al. [11]; Nagrockiene et al. [12]; Ferrari and Padaratz [9]). Regarding this theme, Nagroskiene et al. [12]) highlight that the amount of superplasticizer additive and its interaction with the type of cement, also have influence in the ultrasonic pulse velocity. Besides, it is important to highlight that the type of cement and hydration degree have more influence during the early ages (until 24-48 hours) as shown by results from Sturrup et al. [13]; Elvery and Ibrahim [14] and Evangelista [15].

Cosme-Lopez et al. [16] verified in their work that due to the high correlation found on their experiment, the tests with ultrasound may even replace the ones of compressive strength, for detecting the evolution of the hydration of the cement paste present in concrete. The work from Pereira e Medeiros [5] corroborates this information indicating a linear correlation between compressive strength and ultrasonic pulse velocity with R2 of 0.98 . On the other hand, the work from Capraro et al. [17] had linear relation with R2 ranging between 0.75 and 0.92 , indicating that there is possibility of less precise correlation indices than the ones above 0.90 , already reported. However, Demirboga et al. [18] and Sabbag and Uyanik [19] had exponential relations with R2 between 0.90 and 0.99 , and this last one had one proposal of a model for estimating the compressive strength using data of ultrasonic pulse velocity. According to ASTM 114 [8], the test of ultrasonic pulse velocity represents a viable technology for the diagnosis of structures, because besides allowing the characterization of the material, it is useful to evaluate its integrity and to estimate the compressive strength and the modulus of elasticity of the material. Besides, Hernandez et al. [20] cited that the method of ultrasonic pulse velocity is widely used to verify the density and the elastic parameters of ceramic materials, as indicated by works of Mesquita et al. [21] and Mesquita et al. [22] who made applications of the technique to study historical works built from structural walls with ceramic blocks.

Inside this context, this study aims to evaluate the influence of the type of cement, curing age, shape and humidity of test specimens of concrete on ultrasonic propagation velocity (UPV) readings.

Table 1

Chemical characterization of cements CP V-ARI, CP II-Z-32 and CP IV-32 RS

\begin{tabular}{cccc}
\hline \multirow{2}{*}{ Component } & \multicolumn{3}{c}{ Type of cement } \\
\cline { 2 - 4 } & CP V-ARI & CP II-Z-32 & CP IV-32 RS \\
\hline $\mathrm{CaO}(\%)$ & 60.89 & 54.67 & 45.17 \\
$\mathrm{SiO}_{2}(\%)$ & 18.96 & 22.04 & 28.92 \\
$\mathrm{Al}_{2} \mathrm{O}_{3}(\%)$ & 4.24 & 6.17 & 9.56 \\
$\mathrm{SO}_{3}(\%)$ & 3.00 & 2.69 & 2.31 \\
$\mathrm{Fe}_{2} \mathrm{O}_{3}(\%)$ & 2.66 & 3.10 & 3.83 \\
$\mathrm{MgO}(\%)$ & 3.87 & 3.45 & 2.88 \\
Loss on ignition (\%) & 3.18 & 5.51 & 3.29 \\
Insoluble residue (\%) & 0.81 & 10.96 & 25.33 \\
\hline
\end{tabular}




\section{Table 2}

Physical characterization of cement CP V-ARI, CP II-Z-32 and CP IV-32 RS

\begin{tabular}{|c|c|c|c|}
\hline \multirow{2}{*}{ Type of test } & \multicolumn{3}{|c|}{ Type of cement } \\
\hline & CP V-ARI & CP II-Z-32 & CP IV-32 RS \\
\hline Hot expandability (\%) & 0.14 & 0.58 & 0.40 \\
\hline Setting time of cement (initial) & $3: 40$ & $4: 47$ & $4: 31$ \\
\hline Setting time of cement (final) & $4: 30$ & $5: 59$ & $5: 17$ \\
\hline Normal consistency water (\%) & 29.9 & 27.7 & 30.1 \\
\hline Blaine $\left(\mathrm{cm}^{2} / \mathrm{g}\right)$ & 4351 & 3553 & 4200 \\
\hline \#200 (\%) & 0.03 & 1.62 & 0.46 \\
\hline \#325 (\%) & 0.27 & 11.04 & 2.60 \\
\hline $\begin{array}{c}\text { Compressive strength (MPa) } \\
\text { after } 28 \text { days of curing }\end{array}$ & 51.9 & 37.23 & 44.2 \\
\hline Specific mass $\left(\mathrm{g} / \mathrm{cm}^{2}\right)$ & 3.11 & 2.98 & 2.82 \\
\hline
\end{tabular}

\section{Materials and methods}

In order to reach the proposed goals, a total of 45 cylindrical test specimens $(10 \mathrm{~cm} \times 20 \mathrm{~cm})$ and 9 cubic test specimens with edges of $25 \mathrm{~cm}$ were molded. From this set of samples, 36 cylindrical test specimens were submitted to the test of axial compression according to standard NBR 5739 [23], and nine cylindrical and nine cubic ones were used exclusively for readings of ultrasonic pulse velocity, according to NBR 8802 [10] Test specimens were kept in immersion cure, in lime saturated water, with environment temperature $\left(20 \pm 5{ }^{\circ} \mathrm{C}\right)$ during the whole period of 100 days of the experiment, according to NBR 5738 [24].

\subsection{Materials}

Cements used in the experiment were the CP V-ARI, CP IIZ-32 and CP IV-32 RS, whose chemical properties (executed in a X-ray fluorescence spectrometer X (FRX) PW2424/00 Magix Panalytical) and physical ones are informed in Table 1 and Table 2.

The fine aggregate, from the metropolitan region of Curitiba, was inside the inferior and superior limits of the zone of optimum particle size distribution (Figure 1). The coarse aggregate also comes from the metropolitan region of Curitiba, of basaltic origin, and was inside the granulometric zone $9.5 / 25 \mathrm{~mm}$. For both aggregates, the characterization was obtained from the described by NBR 7211 [25]. The specific mass of the fine aggregate was $2.59 \mathrm{~g} / \mathrm{cm}^{3}$ and of the coarse aggregate was of $2.72 \mathrm{~g} / \mathrm{cm}^{3}$.

The mixing proportion adopted as reference concrete was 1:2.7:3.2 (cement: sand: gravel) and the water/cement ratio was 0.58 , the same one used by Pereira and Medeiros [5]. The slump test obtained from the three traces regarding the three cements were 160 , 180 and 210, regarding CP V-ARI, CP II-Z-32 and CP IV-32 RS, respectively. Water used was potable, provided by the local utility ("Companhia de Saneamento do Paraná - SANEPAR"). Densification was made manually, with standard metal rod, the filling

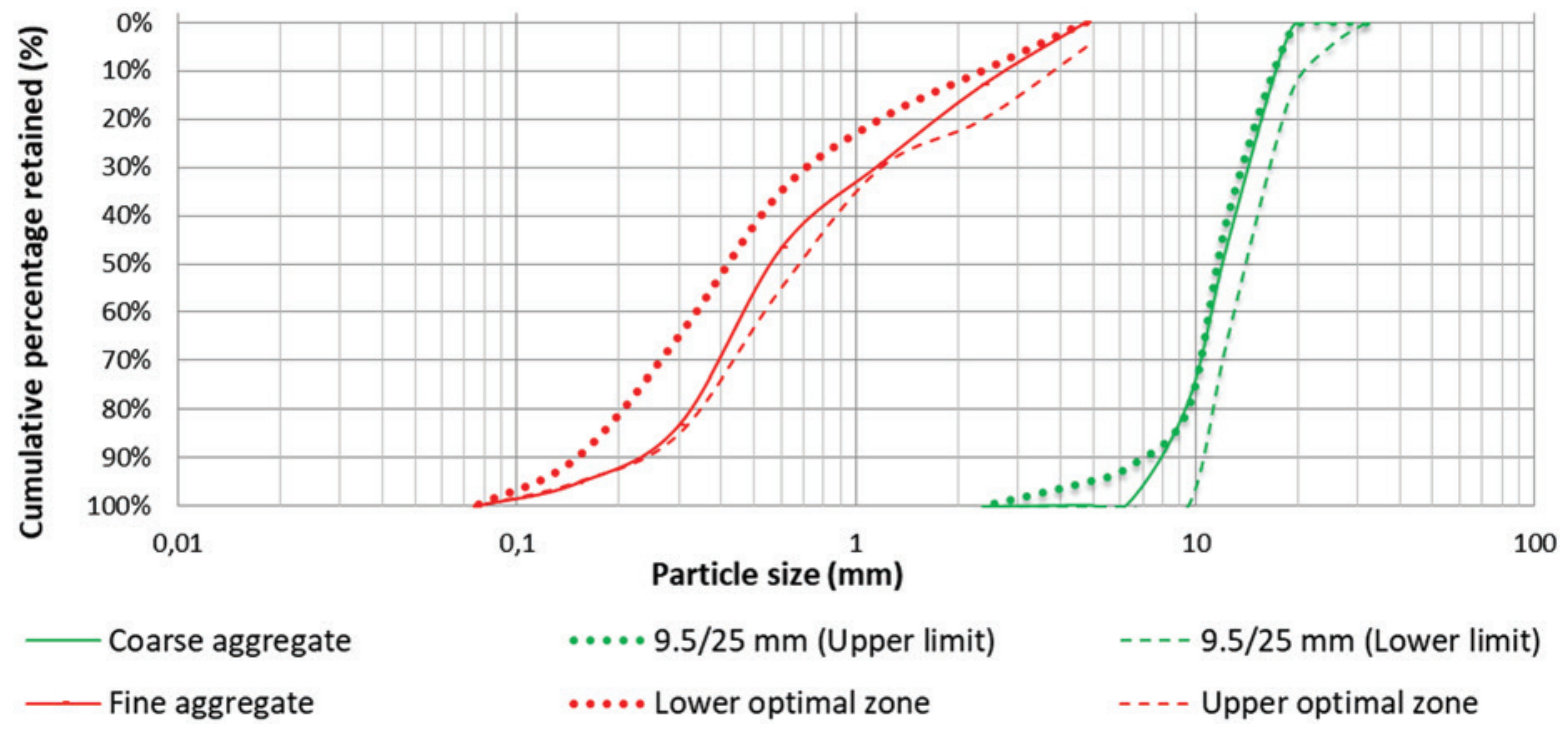

Figure 1

Particle size curve of aggregates for test specimens 


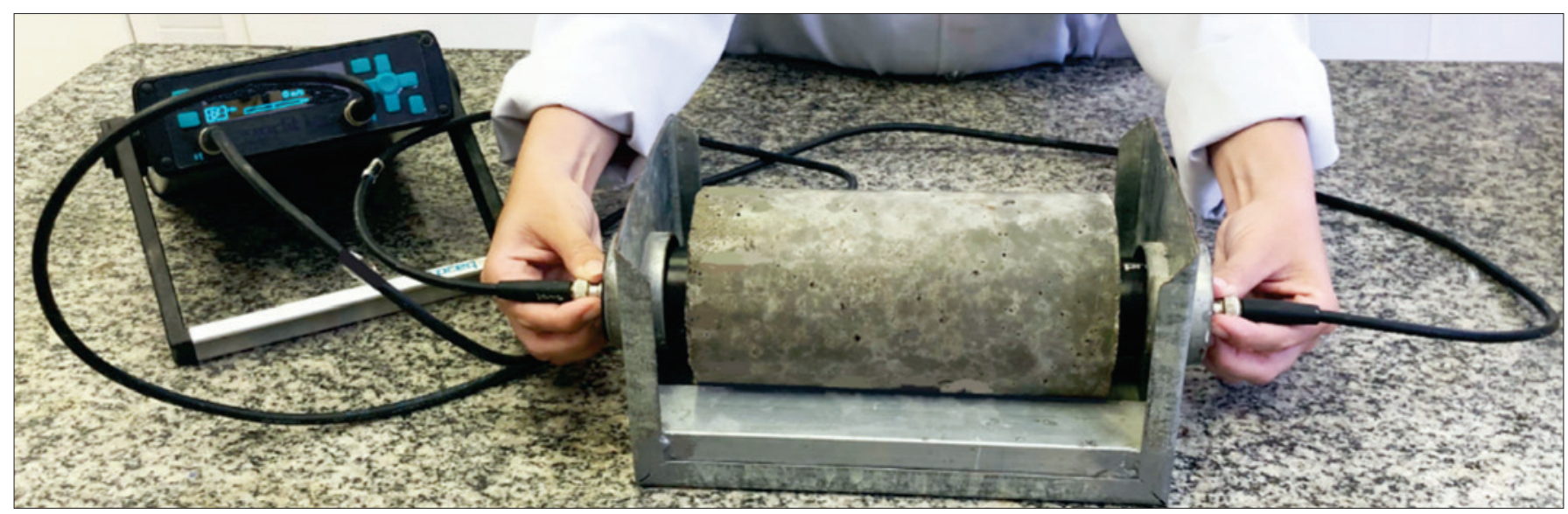

\section{Figure 2}

Transducer positioning mode for ultrasonic pulse emission and reception in cylindrical test specimens $10 \mathrm{~cm} \times 20 \mathrm{~cm}$

of the test specimens being made in 2 layers of concrete for all samples, as precognizes NBR 5738 [24].

\subsection{Ultrasonic Pulse Velocity (UPV) test}

Readings were made with the help of equipment Ultrasonic Pulse Velocity - Pundit Lab, from manufacturer Proceq, constituted of two transducers working together in the measurement (one sender and one receptor of waves). The equipment was configured with transmission/reception frequency of $54 \mathrm{kHz}$, using transducers of $50 \mathrm{~mm}$ of diameter.

All readings were made according to NBR 8802 [10], using the method of direct transmission between transducers, as illustrated in Figure 2. Before each reading, the surface was cleaned, removing any material that may mask the penetration of the sonic beam. Next, for each reading was used the coupling gel indicated by the manufacturer in order to produce the proper contact between transducers and surfaces of the concrete.

In order to ensure the centralization of the readings in each cylin- drical test specimen, a metallic apparatus was used as positioning guide, as illustrated in Figure 2.

\subsection{Evaluation of UPV in fresh concrete}

As illustrated in Figure 3, the test was made with fresh concrete introduced in a cylindrical mold with dimensions of $10 \mathrm{~cm} \times 20 \mathrm{~cm}$ restricted in the base and on the top by two glass plates in order to confine the concrete.

Molding was effected with the cylindrical mold positioned vertically with the base supported in the glass plate. Next, the second glass plate was positioned in the whole of the mold, fixation was made with the screws and the set positioned in horizontally, as shown in Figure 3.

Readings were made using the glass plates as contact surface of transducers. The coupling gel was used for contact of transducers of $54 \mathrm{kHz}$, on the same way that was made in the case of direct coupling in concrete, when the test was made in hardened state. FREIRE et al. [26] did a monitoring procedure of the UPV

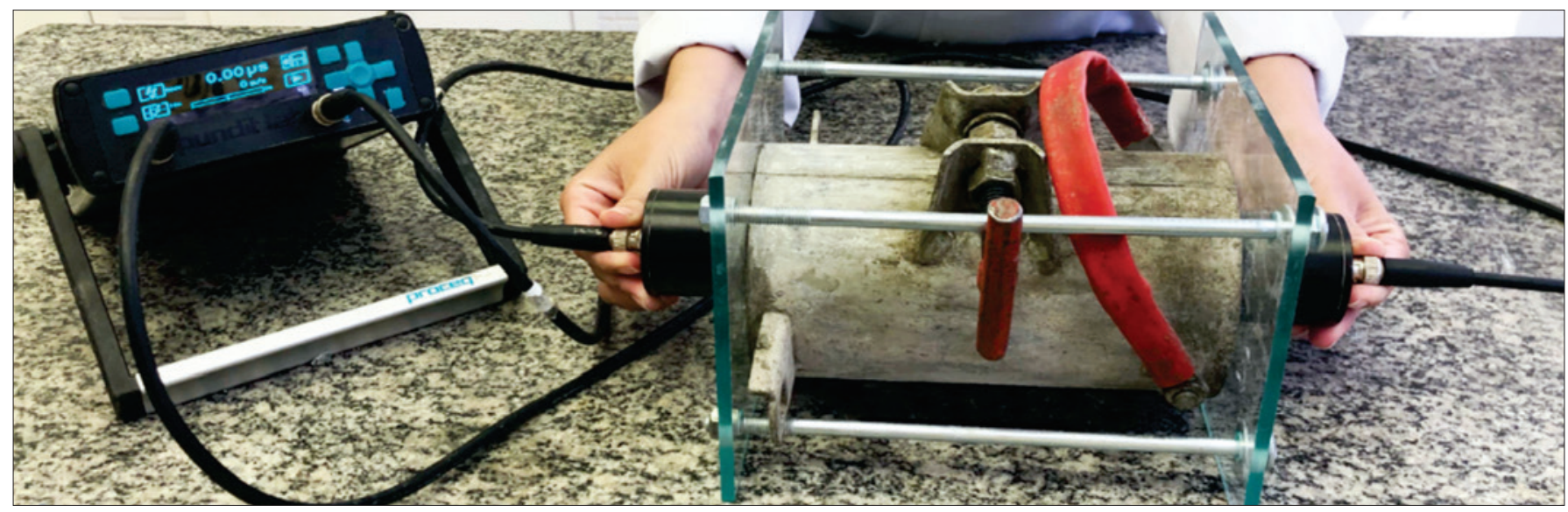

Figure 3

Fresh concrete UPV test with $10 \mathrm{~cm} \times 20 \mathrm{~cm}$ cylindrical shapes and tempered glass plates at the bases 


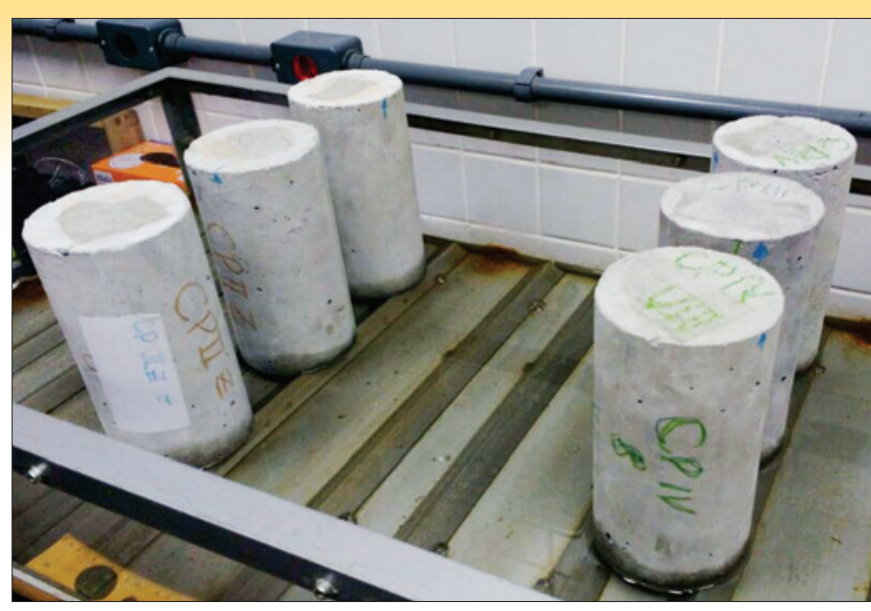

Figure 4

Capillary absorption test of specimens (procedure of NBR 9779 [27])

of concrete in fresh state with a procedure similar to this one. Readings were made at times of $3 \mathrm{~h}, 5 \mathrm{~h}, 7 \mathrm{~h}$ and $9 \mathrm{~h}$ counting from the mixture of dry materials with water. Those reading moments were adopted in order to monitor the UPV between the initial and final setting time of cement, generating information regarding the transition period of concrete between liquid and solid states.

\subsection{Evaluation of UPV in hardened state}

\section{INFLUENCE OF MOISTURE}

Capillary water absorption in hardened concrete was evaluated for ages of 28 days, 70 days and 91 days of cure for three different cements, according to NBR 9779 [27]. For executing the test, the test specimens passed by a kiln-drying, at a temperature of $100{ }^{\circ} \mathrm{C}$ until mass constancy, in order to determine the dry mass and the UPV in dry condition. In possession of the dry test specimens, they were positioned over supports, filling with water the test recipient, in a way that the water level remained in $5 \pm 1 \mathrm{~mm}$ over its inferior face (Figure 4). Posteriorly mass and UPV of the test specimens were determined in $3 \mathrm{~h}, 6 \mathrm{~h}, 24 \mathrm{~h}$, $48 \mathrm{~h}$ and $72 \mathrm{~h}$, in order to verify the influence of capillary water absorption in the UPV.

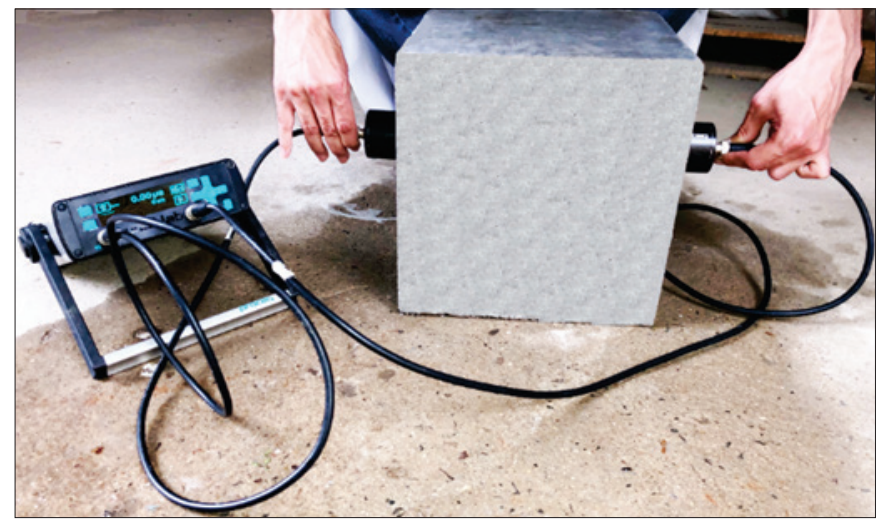

\section{Figure 5}

Transducers positioning mode for ultrasonic pulse emission and reception in $25 \mathrm{~cm}$ cubic edge specimens
INFLUENCE OF COMPRESSIVE STRENGTH

The test of axial compressive strength was made according to NBR 7215 [28], whose test specimens were retired from immersion and the reading made with the ultrasound equipment moments before the rupture, with test specimens still saturated for ages of 7 days, 14 days, 18 days, 70 days and 91 days of cure submersed in saturated water with cal.

\section{INFLUENCE OF THE MOLD IN THE TEST SPECIMEN}

Three cylindrical test specimens $(10 \mathrm{~cm} \times 20 \mathrm{~cm})$ and three cubic ones ( $25 \mathrm{~cm}$ of edges) were molded for each one of the three types of cements (CP V-ARI, CP II-Z-32 and CP IV-32 RS), in a total of nine cylindrical and nine cubic ones. Readings of UPV, with test specimens always saturated with dry surface, were made in ages of $7,14,28,70$ and 91 days, using transducers of $54 \mathrm{kHz}$, coupled in the test specimens with conductive ultrasound gel. For cylindrical ones was used the metallic support in order to align the transducers with the center of the test specimens. For the cubic ones, the center of the test specimens was marked with the help of a caliper in order to also facilitate the alignment of transducers (Figure 5).

\section{STATISTICAL ANALYSIS}

In order to corroborate results and verify the difference and significance or not of data obtained, a Variance Analysis (ANOVA: one criteria) and Tukey's test a posteriori were made, with 95\% of trust with the help of the free Software Bioestat - version 5.3.

\section{Results and discussions}

\subsection{Ultrasonic pulse velocity of concrete in fresh state}

In this stage of the study, it was sought to verify the behavior of the ultrasonic pulse velocity during the first hours of concrete hydration. In other words, in the transition period between the plastic state and the one of porous solid. This way, Figure 6 shows data from the readings of times of $3 \mathrm{~h}, 5 \mathrm{~h}, 7 \mathrm{~h}$ and $9 \mathrm{~h}$ after the mixture of dry materials with water. According to Mehta and Monteiro [1] hydration is influenced by the fineness of the cement, water/cement ratio, cure temperature, presence of additives and additions

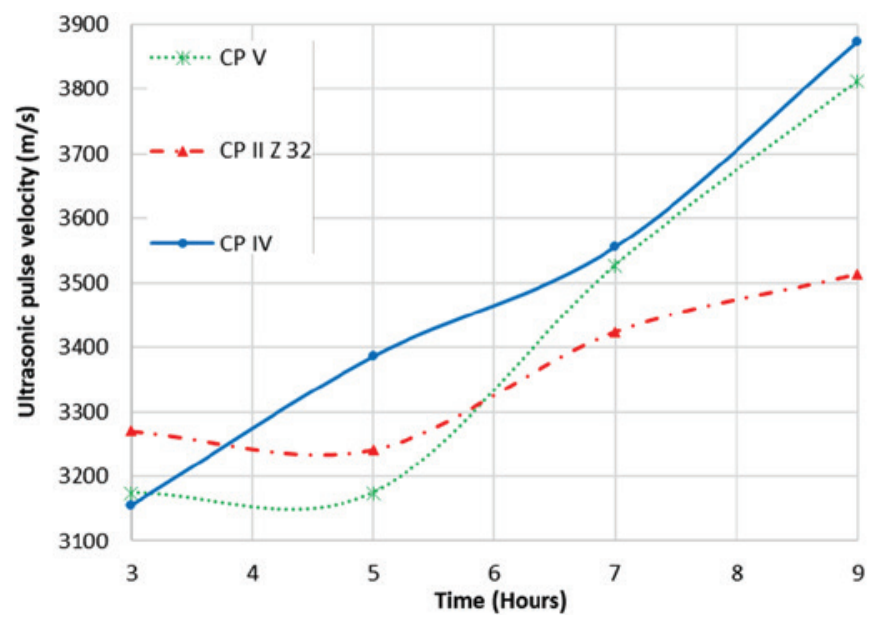

\section{Figure 6}

Ultrasonic pulse velocity for the three different types of cement in the first hours of hydration 
in cement. Based on the statistical test applied, it was not possible to verify significant differences, because $p$-value was greater than 0.05 for all reading times. As the trend of results was not clear, other studies focusing specifically on UPV in fresh state are needed in order to have more effective conclusions.

\subsection{Ultrasonic pulse velocity of concrete in hardened state}

In Figure 7 is presented the evolution of the compressive strength and ultrasonic pulse velocity along time for the three types of cements studied (CP V-ARI, CP II-Z-32 and CP IV-32 RS), as well as the correlation for both parameters. It is important to highlight that

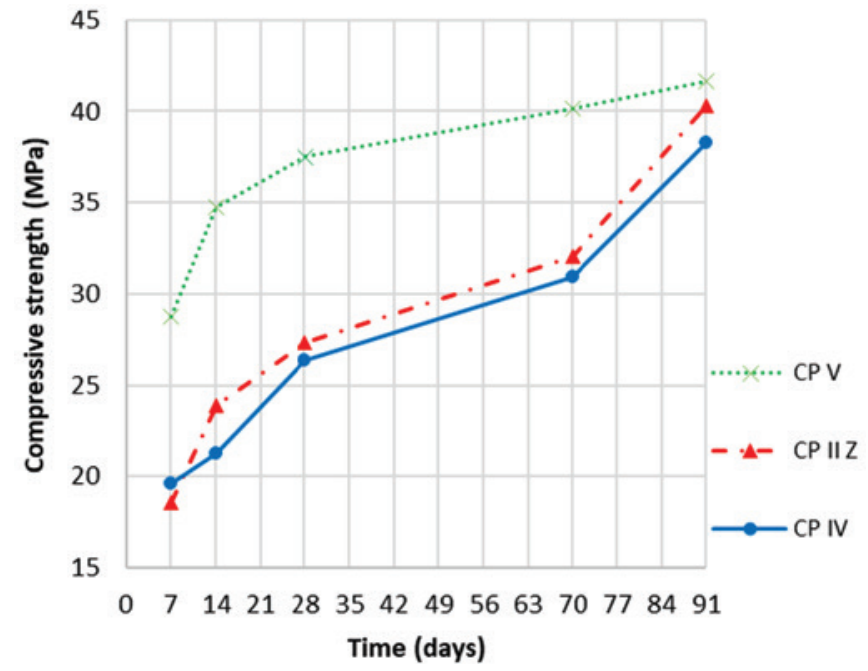

(a) the correlation was made for the readings obtained in the same test specimens that were broken.

It is observed in Figure 7 (a) that the compressive strength of the three types of cement increased along time and this increase from the 7 until the 91 days of cure was of $45 \%$ to CP V, $117 \%$ to CP II $Z$ and of $95 \%$ to CP IV. It is interesting to observe that there was a sharp increase in the compressive strength of cements CP II Z 32 and CP IV from 70 to 91 days, coming from late pozzolanic reactions regarding the hydration of cement additions. Mehta and Monteiro [1] state that concretes without mineral additions in cement and with levels of clinker over $90 \%$ (CP V) gain approximately $90 \%$ of resistance at 28 days of wet cure. For this study the concrete dosed with cement $\mathrm{CP} \vee$ had $89 \%$ of the resistance gain at

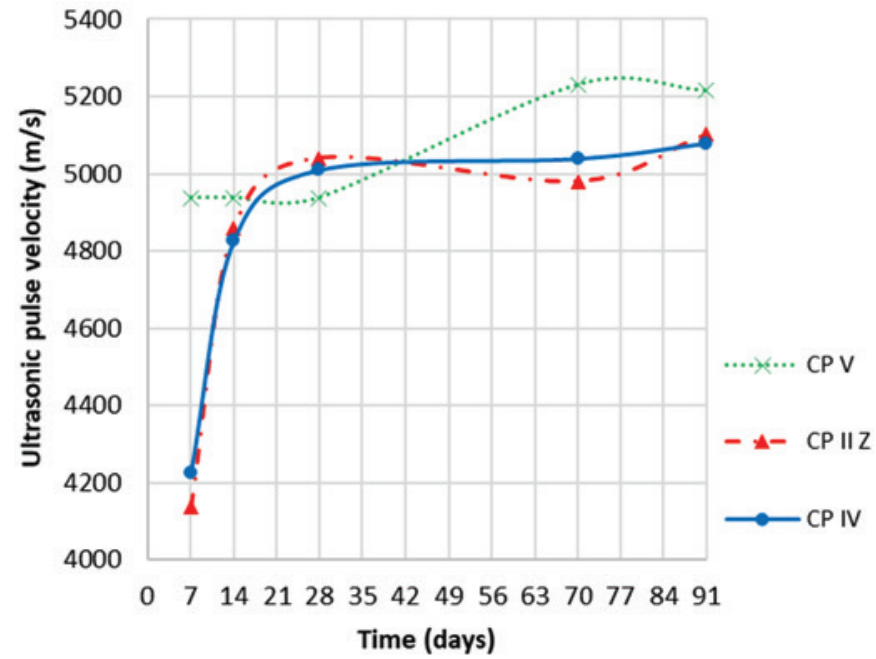

(b)

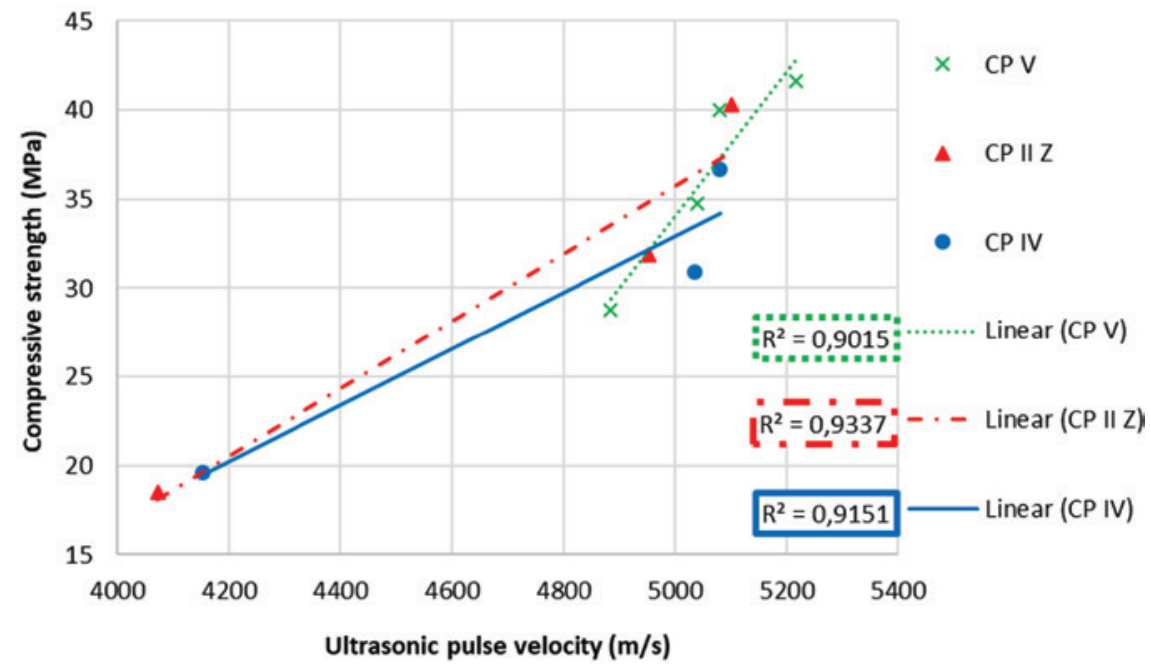

(c)

\section{Figure 7}

Evolution of concrete strength and UPV over time: a) compressive strength; b) ultrasonic pulse velocity as a function of the shape of test specimen; c) correlation between compressive strength and ultrasonic pulse velocity 
28 days (compared with rupture at 91 days) and for cements CP II $Z$ and CP IV the gain was approximately of $55 \%$, which was also expected because, according to Mehta and Monteiro [1] the pozzolanic additions have smaller hydration speed regarding clinker. It was possible to statistically observe significant differences regarding compressive strength when comparing $\mathrm{CP} V$ with $\mathrm{C}$ II $\mathrm{Z}$ and $C P \vee$ with $C P$ IV until the age of 70 days and non-significant between CP II Z with CP IV until this same age. Regarding the age of 91 days, no cement had a significant difference.

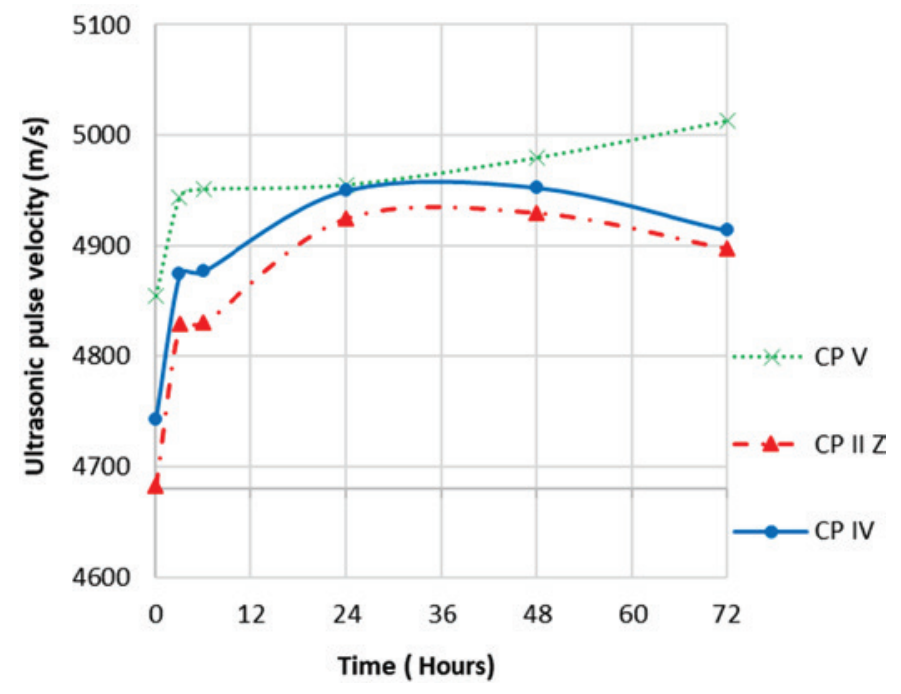

(a)
By means of Figure 7 (b) it is observed that the ultrasonic pulse velocity increased only $6 \%$ from 7 until 91 days for CP $\vee$ and approximately $23 \%$ for cements CP II Z and CP IV, being possible to verify statistical difference in the comparison of ages regarding the type of cement, corroborating the influence of cure time/degree of hydration in the increase of ultrasound speed. After executing the statistic test, it was not possible to verify statistic differences for any of the ages, when comparing CP II Z with CP IV. In comparison of $\mathrm{CP} \vee$ with $\mathrm{CP} \| \mathrm{Z}$, it was possible to observe differences in

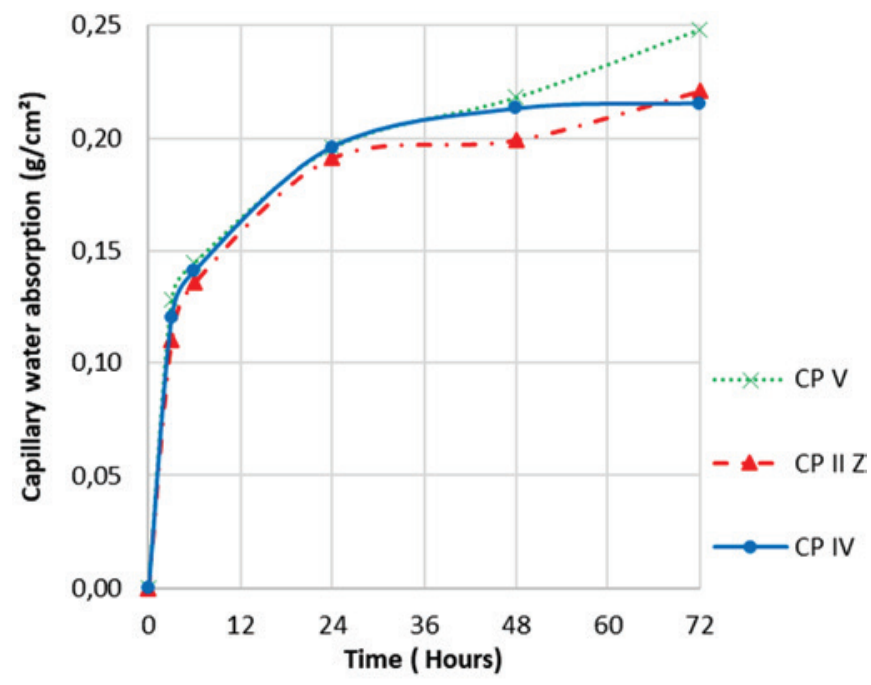

(b)

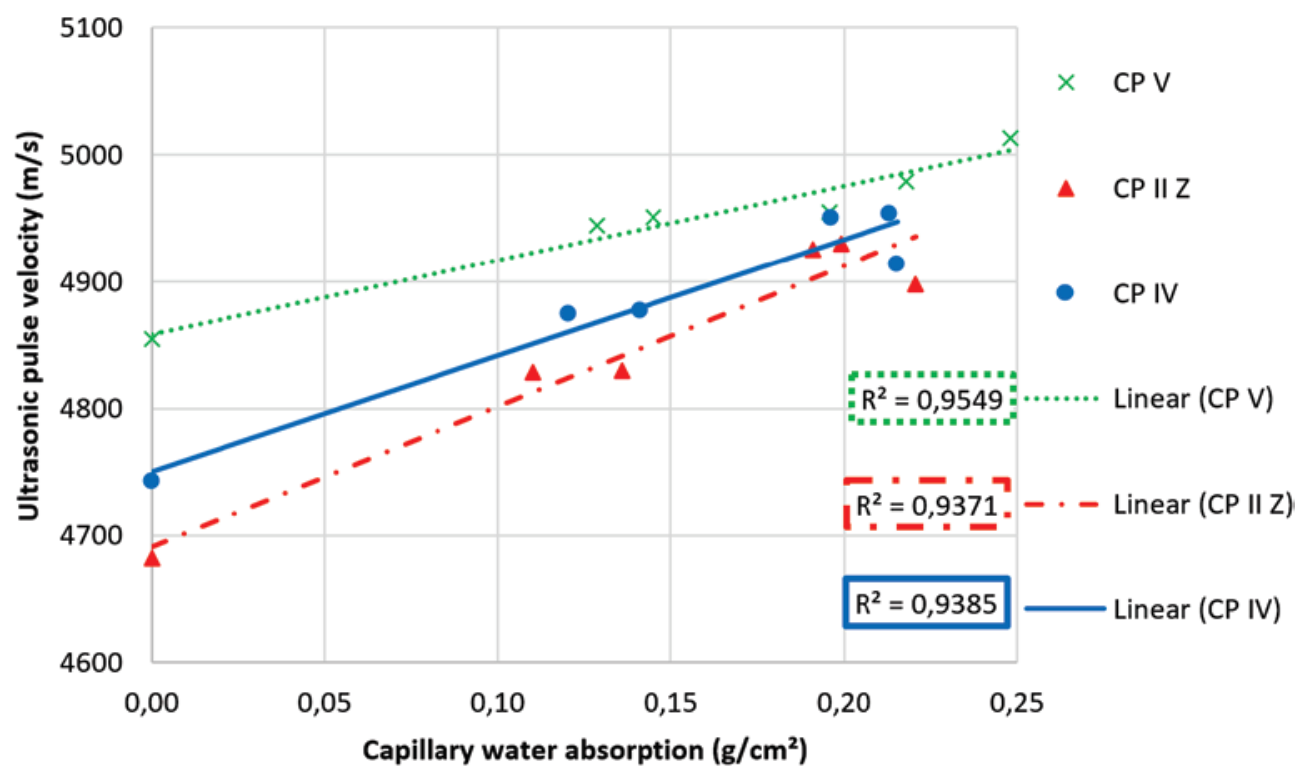

(c)

\section{Figure 8}

Physical tests over $72 \mathrm{~h}$ for the three types of cement at the age of 28 days: (a) ultrasonic pulse velocity throughout the absorption test; b) capillary water absorption.; c) correlation between ultrasonic pulse velocity and capillary water absorption 
the ages of 7 and 70 days. On the comparison of $\mathrm{CP} \vee$ with $\mathrm{CP}$ $\mathrm{IV}$, the ages with differences were 7 days, 14 days and 70 days. As happened with the compressive strength in the age of 91 days, none of the cements had significant differences to UPV. Comparing with experiments of Sturrup et al. [13], Elvery and Ibrahim [14] and Evangelista [15], this work confirms that the type of cement and the hydration degree have more influence on the first ages, however, at least for materials used in this research, not only until 24-48 hours of the mixture of dry materials with water.

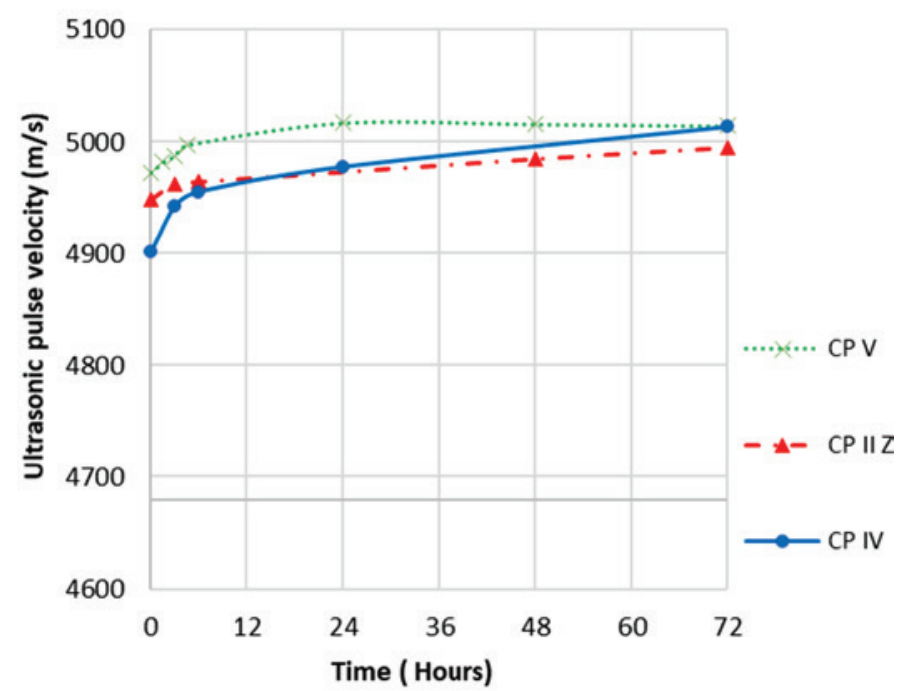

(a)
This information is according to work of Malhotra e Carino [29], stating that the effect of concrete age over UPV is similar to the effect of age over the compressive strength of concrete. According to authors, in the beginning the speeds grow more quickly, while in more advanced ages this growth is reduced. As found in Figure 7, Malhotra and Carino [29] state that the tendency of growth of the UPV is similar with the curve tension versus age of a given concrete, but UPV reaches a level of constancy before than in the case of compressive strength.

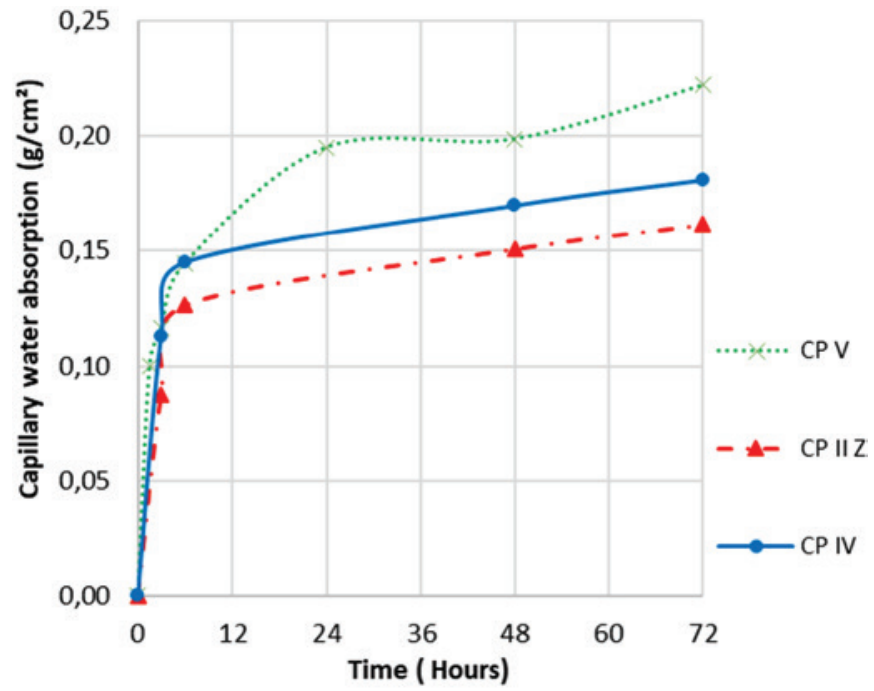

(b)

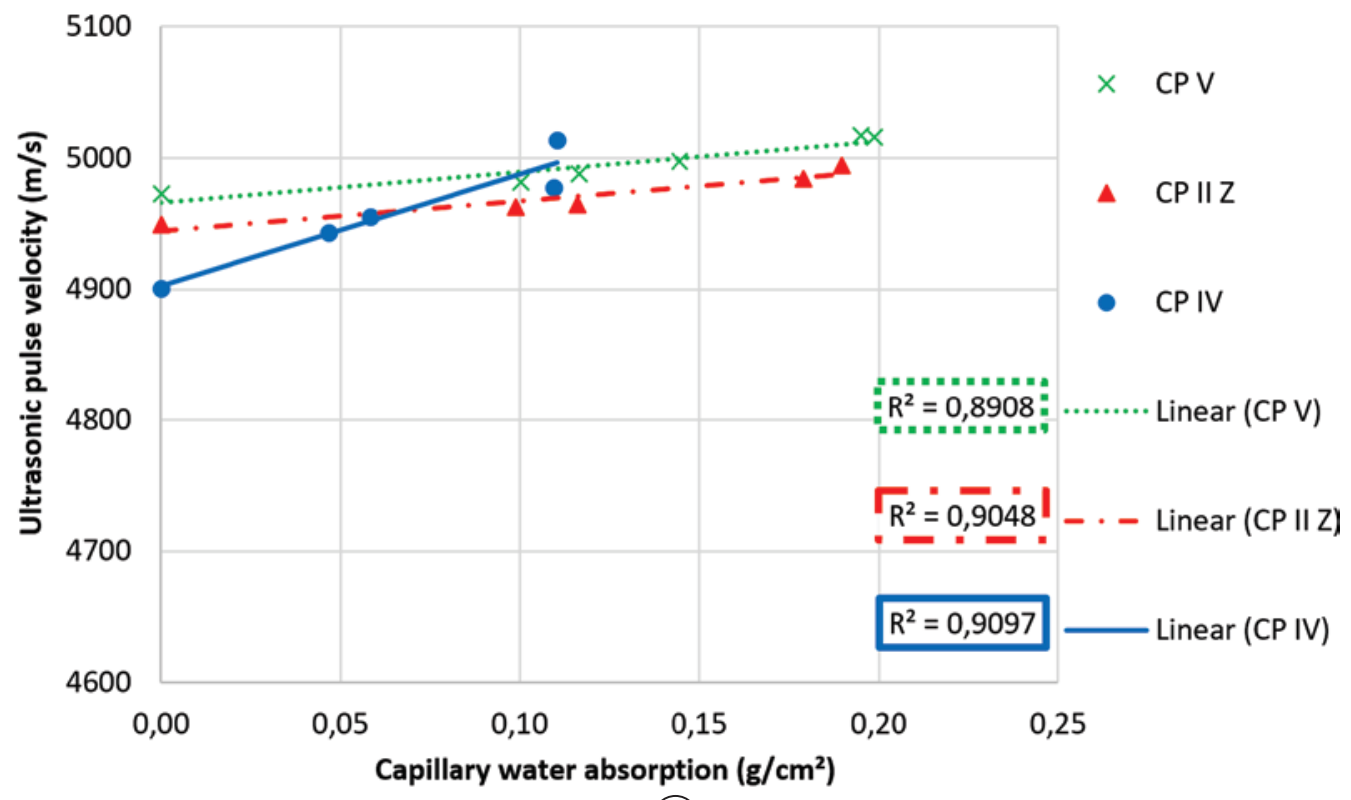

(c)

\section{Figure 9}

Physical tests over $72 \mathrm{~h}$ for the three types of cement at the age of 70 days: (a) ultrasonic pulse velocity throughout the absorption test; b) capillary water absorption; c) correlation between ultrasonic pulse velocity and capillary water absorption 
Besides, it was noted that the ultrasonic speed increased more rapidly for CP II Z and CP IV during the first ages and continued at a slower rate until reaching 91 days, those results are in accordance with work of ABO-QUDAIS [30], where the author studied the effect of the parameters of the concrete mix in the propagation of ultrasound waves, obtaining readings starting from $4200 \mathrm{~m} / \mathrm{s}$ at 28 days and with values near $5000 \mathrm{~m} / \mathrm{s}$ at 90 days of cure. Those data corroborate with data from Figure 7 (b) that also varied between 4100 until $5300 \mathrm{~m} / \mathrm{s}$.

Still according to ABO-QUDAIS [30] the volume of capillary pores in the paste of hydraulic cement decreases with time, since the degree of hydration of the cement depends upon the curing age, despite other conditions of cure such as temperature and moisture that were kept constant during the study of the author. This information justifies the increase of UPV over healing time, as happened in Figure 7 (b).

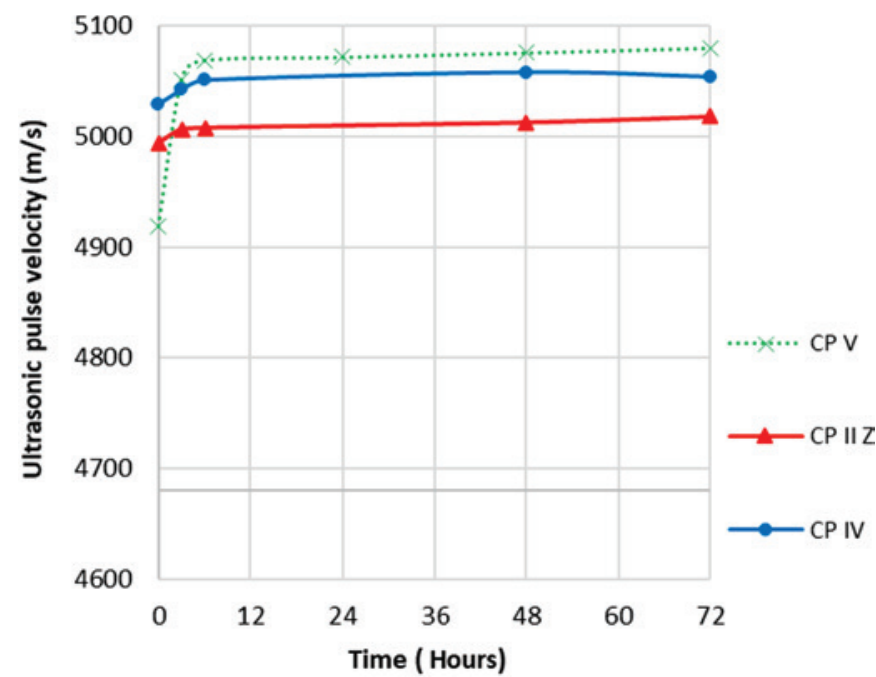

(a)
As it is possible to observe in Figure 7 (c), good linear correlations were obtained $\left(R^{2} \geq 90 \%\right)$ between resistance to average compressive strength and the ultrasonic pulse velocity for concretes obtained with the three types of cement. The linear adjustment was reasonable for the description of this relation, a conclusion also obtained by Pereira e Medeiros [5] studying three traces of concretes with water/cement ratios of $0.43,0.50$ and 0.59 , which correlated compressive strength to compression versus the ultrasonic pulse velocity $(\mathrm{m} / \mathrm{s})$ by means of a linear regression whose $R^{2}$ was equal to 0.9972 .

In contradiction, for Del Río et al. [31] the best way of presenting the correlation between compressive strength and ultrasonic speed is exponentially, but as it was already cited before, there are many factors influencing the readings and there is no consensus about the better correlation method, be it linear, polynomial or exponential.

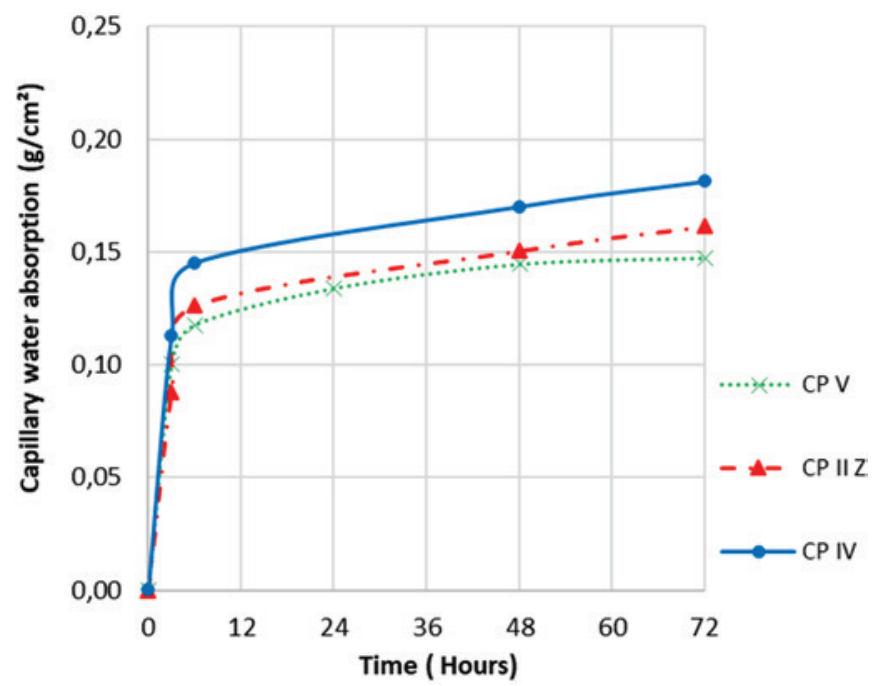

(b)

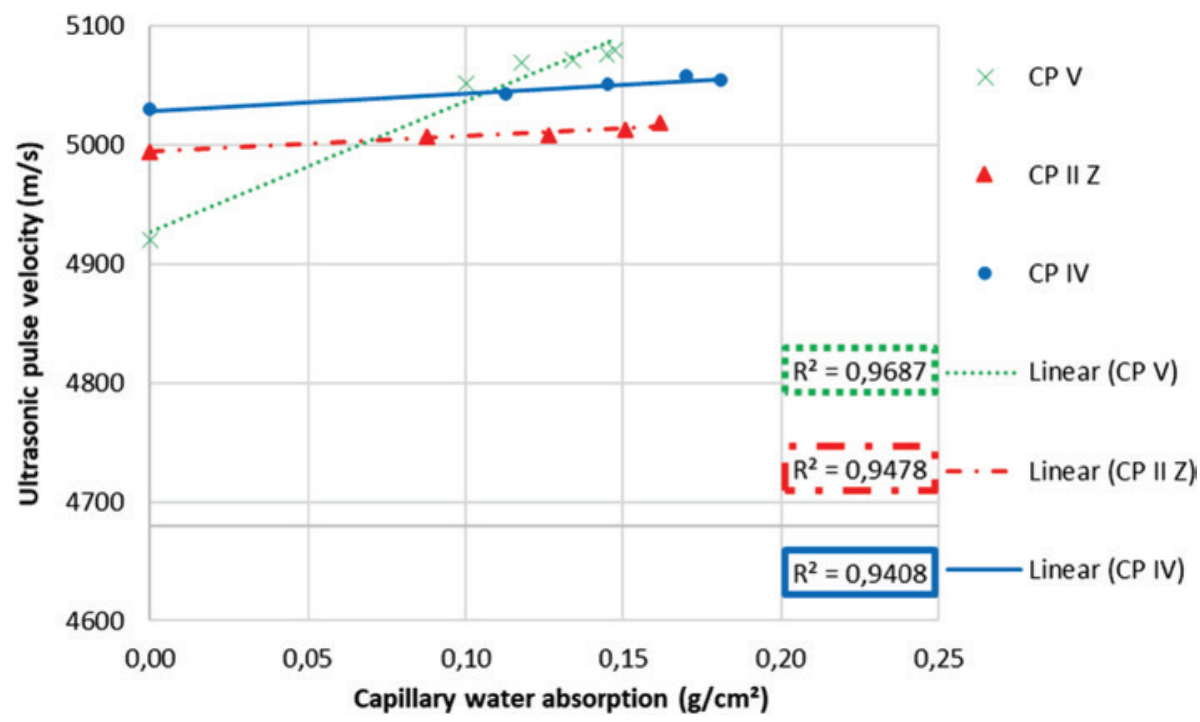

(c)

\section{Figure 10}

Physical tests over $72 \mathrm{~h}$ for the three types of cement at the age of 91 days: (a) ultrasonic pulse velocity throughout the absorption test; b) Capillary water absorption; c) correlation between ultrasonic pulse velocity and capillary water absorption 


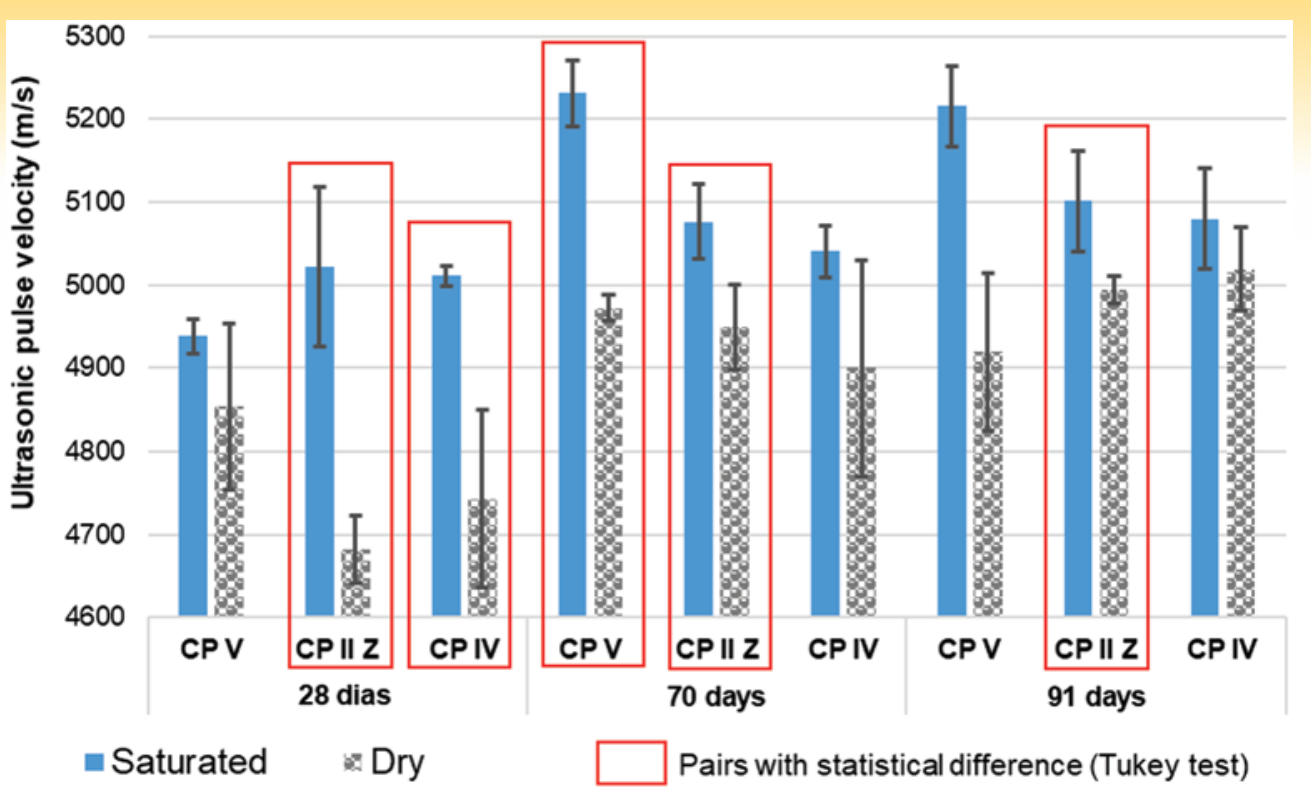

\section{Figure 11}

Ultrasonic pulse velocity for the three types of cements at three ages, comparing saturated and dry test specimens

In Figure 8 are presented results of ultrasonic pulse velocity and capillary water absorption along $72 \mathrm{~h}$ of test of water suction by capillarity for the three types of cements in the age of 28 days of cure. For this study the increase of ultrasonic pulse velocity along the 72 hours of the absorption test was of $3 \%, 5 \%$ and $4 \%$ for cements CP V, CP II Z and CP IV, respectively, whereas in comparison of $\mathrm{CP} \vee$ with CP II Z there was significant difference only at times of $3 \mathrm{~h}$ and $72 \mathrm{~h}$. Comparing CP II with CP IV, there were differences only at the time of $72 \mathrm{~h}$. Comparing CP ॥ Z with CP IV there was no difference in any of the times. Water input in concrete should cause increase of UPV because the sound is transported with more speed in water than in the empty pores of concrete. However, the magnitude of the increase in UPV along the test of absorption by capillarity was small. Generally, it is possible to say that this happened due to the characteristics of the test of water absorptions by capillary suction, which involves the penetration of a small amount of water in concrete (12 grams in the case of the smaller absorption of $0.15 \mathrm{~g} / \mathrm{cm}^{2}$ and 20 grams for the case of greater absorption, which was of $\left.0.25 \mathrm{~g} / \mathrm{cm}^{2}\right)$. In the test, water penetrates in the test specimen only by the face in contact with the water blade, so the moisture becomes heterogeneously distributed in the test specimens of concrete. This way, during the test the concrete increases the moisture but remains far from saturation, this being the justification for the degree of influence of the UPV along the test is small and not being possible to verify the statistical influence of the type of cement for the results of absorption observed.

Figure 8 (c) presents the linear correlation between UPV and capillary water absorption. Values of $\mathrm{R}^{2}$ are all over 0.90 , indicating the existence of influence with direct relation between water input in concrete and UPV values.

In Figure 9 are presented the results of ultrasonic pulse velocity and capillary water absorption by along $72 \mathrm{~h}$ for the three types of cement at the age of 70 days of cure.

Figure 9 shows the results of ultrasonic pulse velocity and water absorption along $72 \mathrm{~h}$ of test of water suction by capillarity for the three types of cement at the age of 70 days of cure. After statistical analysis it was verified difference in UPV only comparing CP V with $\mathrm{CP}$ IV in the time of $24 \mathrm{~h}$ of test. However, it must be observed that the range of variation of UPV's data is smaller for 70 days (4900 $-5000 \mathrm{~m} / \mathrm{s}$ ). Besides, as expected, due to the increase of the hydration degree, values of absorption were smaller for concretes cured during 70 days, with significant difference when comparing $\mathrm{CP} \vee$ with $\mathrm{CP}$ IV and of CP II Z with CP IV at ages of $3 \mathrm{~h}$ and $6 \mathrm{~h}$. However, for comparing CP V with CP II Z, it was not possible to observe differences. But it is important to highlight in Figure 9, that the correlation between UPV and capillary water absorption has values of $R^{2}$ greater than 0.89 . Comparing correlation graphics for 28 days (Figure 8 ) with the ones of 70 days (Figure 9) it is observed that the amplitude of the influence of absorption is greater in the first case because at 70 days hydration is more advanced and the concrete less porous.

In Figure 10 are presented results of ultrasonic pulse velocity and capillary water absorption along $72 \mathrm{~h}$ for the three types of cement at the age of 91 days of cure. After statistic evaluation, when comparing CP V with CP II Z and CP II Z with CP IV, it was only observed difference in UPV on times of $6 \mathrm{~h}$ and $72 \mathrm{~h}$, but it was not observed difference between CP V with CP IV in any of the times. In this case, there was less variation of water absorption and UPV, explained by the fact of this being the reading age with more time of submersed cure, in other words, with more degree of hydration. It is worth to highlight that it was not possible to observe statistical difference in absorption for the three types of cement.

Evaluating Figure 10 there was once again a direct relation between UPV and the testing time of capillary water absorption by suction, indicating that the input of water in concrete increases UPV.

In Figure 11 is presented the ultrasonic pulse velocity for the three types of cement and with the two degrees of moisture (dry and saturated test specimens). In this case, the influence of moisture is even clearer because the difference is more extreme, dry and saturated. Using the statistical technique ANOVA with Tukey's test a posteriori, with $95 \%$ of significance, it is possible to state that there is difference between the UPV of dry and saturated test specimens, with the exception of CP V at day 28, CP IV at 70 days and CP IV at 91 days. Thus, the dry concrete has empty pores as a factor making difficult the transportation of the sound waves because the ultrasonic pulse velocity is smaller in the air than in the 


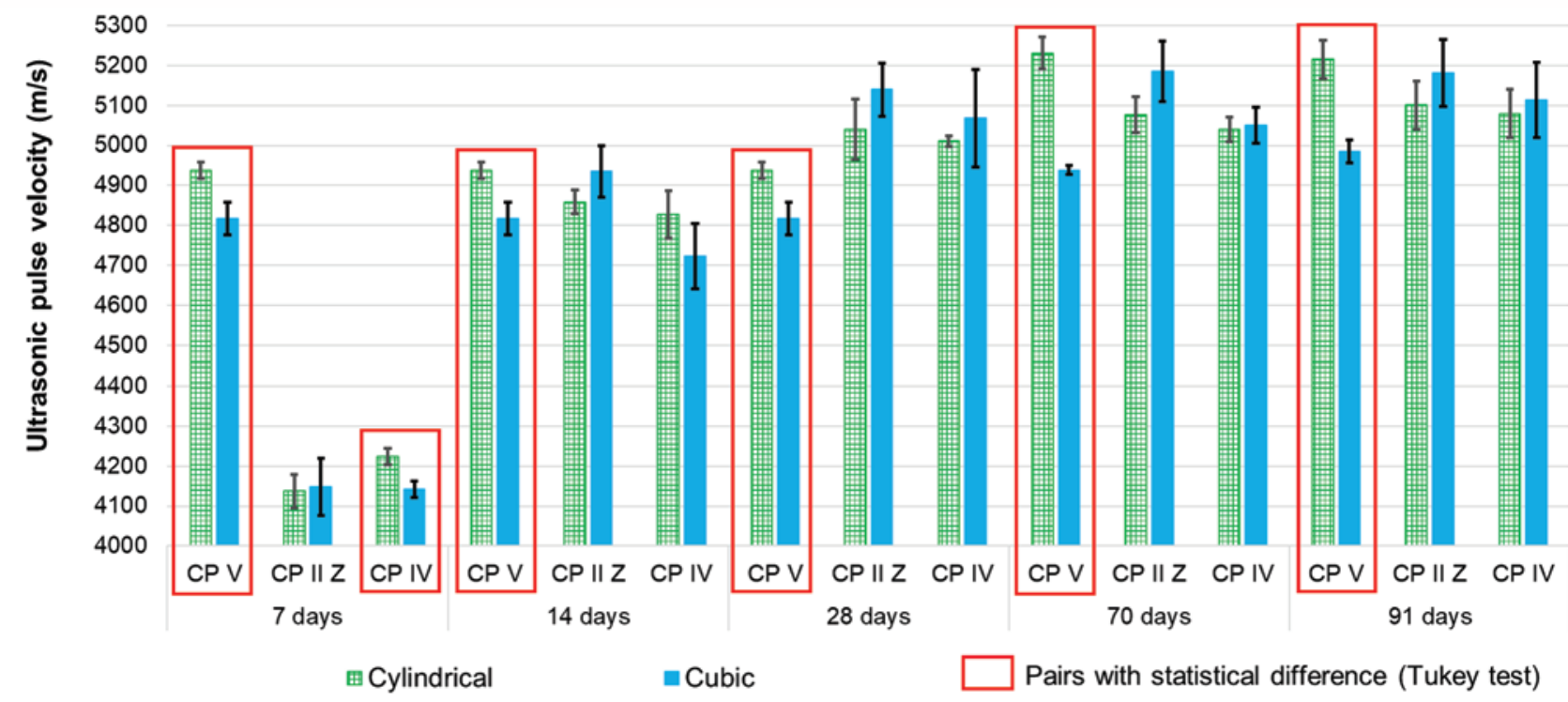

Figure 12

Comparison of UPV measurements on $10 \mathrm{~cm} \times 20 \mathrm{~cm}$ cylindrical test specimens and $25 \mathrm{~cm}$ edge cubes for three types of cement at different ages

solid. When concrete becomes saturated, UPV has a tendency of increasing, because pores that are now empty are filled with water transported with more speed than the empty pores. This information is according to works of Naik et al. [3] and of Ohdaira and Masuzawa [32].

Figure 12 shows the comparison of readings executed in cylindrical test specimens of $10 \mathrm{~cm} \times 20 \mathrm{~cm}$ and cubic ones with $25 \mathrm{~cm}$ of edge for all series studied. In most of the cases, it is possible to state that the shape of the test specimens did not have statistical difference in the readings, except CP $\mathrm{V}$ in all ages and CP IV at 7 days. The fact of not happening changes with the variation of shape and dimensions (in most of the comparison pairs) asserts that the measurement of the ultrasonic pulse velocity is effectively dependent of the variation of the material, this being a positive point for comparing results among different experimental studies regarding works from other authors.

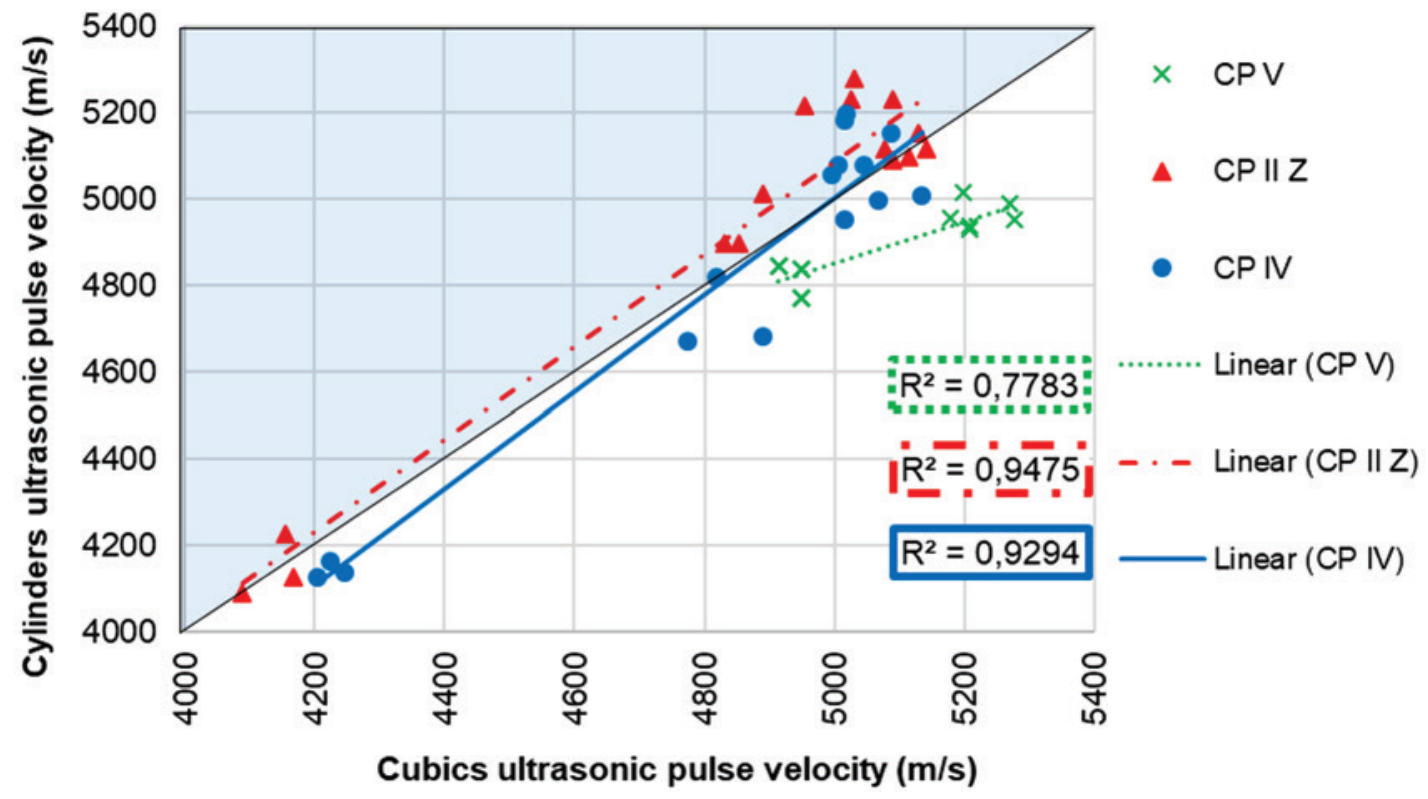

Figure 13

Correlation between UPV measurement in $10 \mathrm{~cm} \times 20 \mathrm{~cm}$ cylindrical test specimens and $25 \mathrm{~cm}$ cubic edge test specimens 
Figure 13 shows the linear correlation of the ultrasonic pulse velocity in cylindrical and cubic test specimens for each one of the three types of cement. It is verified that the trend line for CP II Z and CP IV became very near the line of 45 degrees regarding the $x$ axis. The behavior for the case of $\mathrm{CP} \vee$ was different so that the angular coefficient of the trend line regarding the $x$ axis was less than 45 degrees. This confirms the comparison of averages by Tukey's test, reaffirming that in the case of CP V the UPV data are not equivalent for cylinder as well as for cube.

\section{Conclusions}

This experimental research allowed to establish the conclusions listed next:

With the correlation established between compressive strength and ultrasonic pulse velocity, it is possible to find that satisfactory linear relations were obtained for the three cements studied, with values of $\mathrm{R}^{2}$ over 0.89 ;

- It was possible to verify statistical difference in the comparison of ages regarding the type of cement, corroborating the influence of healing time/hydration degree in the increase of ultrasonic pulse velocity;

- The type of cement had influence on UPV until the reading of 70 days when comparing $C P \vee$ with $C P \| Z$ and $C P \vee$ with $C P$ IV, differently from what some authors state, who report to have found effect of the type of cement only until 24-48 hours after mixing the dry materials with water;

- The absorption test caused little variation on UPV, which became even smaller as the time of cure increased between 28 and 91 days;

- The comparison between dry and saturated concrete showed difference in UPV, so that the saturated concrete always had greater values of UPV. The exception was CP V ARI, which behaved differently from the others;

- The difference of ultrasonic pulse velocity (UPV) between test specimens with different geometries (cylindrical and cubic) was under $200 \mathrm{~m} / \mathrm{s}$ for most of the pairs compared. This confirms conclusions from other studies indicating that the variation of the geometry of the test specimen does not interfere in the propagation of ultrasonic waves. The exception was $\mathrm{CP} V$ in all ages, as happened in the comparison between dry and saturated concrete.

\section{Acknowledgments}

The authors express their gratitude to the Brazilian agencies CNPq, CAPES and Foundation Araucária by the scholarship and financial support, as well as to the Graduate Program in Civil Construction Engineering (PPGECC) from the Federal University of Paraná (UFPR), and to the research group of Pathology and Recovery of Buildings (PRC).

\section{References}

[1] P. K. MEHTA and P. J. M. MONTEIRO, Concreto: Microestrutura, Propriedades e Materiais, $2^{a}$ edição. São Paulo, 2014.

[2] H. F. W. TAYLOR, Cement chemistry, $2^{\circ}$. London: Thomas Telford Ltda, 1997.
[3] T. R. Naik, V. M. Malhotra, and J. Popovics, "The ultrasonic pulse velocity method," in Handbook on non-destructive testing of concrete, $2^{\text {a }}$ edition., New York: CRC Press, 2004, pp. 84-97.

[4] A. M. NEVILLE, Propriedades do Concreto, 2a ${ }^{\mathrm{a}}$. São Paulo: Editora Pini Ltda., 2015.

[5] E. PEREIRA and M. H. F. MEDEIROS, "Ensaio de 'Pull Off' para avaliar a resistência à compressão do concreto: uma alternativa aos ensaios normalizados no Brasil," RIEM - Rev. IBRACON Estruturas e Mater., vol. 5, no. 6, pp. 757-768, 2012.

[6] A. L. CASTRO, S. C. ANGULO, P. C. BILESKY, R. F. C. SANTOS, L. T. HAMASSAKI, and E. SILVA, "Métodos de ensaios não destrutivos para estruturas de concreto.," Techne Rev. Tecnol. da Construção, vol. 17, pp. 56-60, 2009.

[7] J. H. BUNGEY, S. G. MILLARD, and M. G. GRANTHAM, Testing of concrete in structures, $4^{\text {a }}$ Edição. New York: Taylor \& Francis, 2006.

[8] ASTM - AMERICAN SOCIETY FOR TESTING AND MATERIALS, "ASTM E114 - Standard Practice for Ultrasonic Pulse-Echo Straight-Beam Contact Testing," West Conshohocken, PA, USA, 2015

[9] V. J. FERRARI and I. J. PADARATZ, "Aplicação de ondas ultra-sônicas na detecção das primeiras fissuras em vigas de concreto armado e na avaliação da resistência à compressão," Acta Sci. Technol., vol. 25, no. 2, pp. 185-191, 2003.

[10] ABNT - ASSOCIAÇÃO BRASILEIRA DE NORMAS TÉCNICAS, "NBR 8802 - Concreto endurecido - Determinação da velocidade de propagação de onda," Rio de Janeiro/RJ, 2013.

[11] N. De Belie, C. U. Grosse, J. Kurz, and H.-W. Reinhardt, "Ultrasound monitoring of the influence of different accelerating admixtures and cement types for shotcrete on setting and hardening behaviour," Cem. Concr. Res., vol. 35, no. 11, pp. 2087-2094, Nov. 2005.

[12] D. Nagrockiene, I. Pundienè, and A. Kicaite, "The effect of cement type and plasticizer addition on concrete properties," Constr. Build. Mater., vol. 45, pp. 324-331, Aug. 2013.

[13] H. STURRUP, V. R.; VECCHIO, F. J.; CARATIN, "Pulse Velocity as a Mesuare of Concrete Compressive Strength," in Nondestructive Testing of Concrete, Special Pu., Detroit: American Concrete Institute (ACI), 1984, pp. 201-228.

[14] R. H. Elvery and L. A. M. Ibrahim, "Ultrasonic Assessment of Concrete Strength At Early Ages.," Mag. Concr. Res., vol. 28, no. 97, pp. 181-190, 1976.

[15] A. C. J. EVANGELISTA, "Avaliação da resistência do concreto usando diferentes ensaios não destrutivos," 2002.

[16] M. F. COSMES-LÓPEZ, F. CASTELLANOS, and P. F. de J. CANO-BARRITA, "Ultrasound frequency analysis for identification of aggregates and cement paste in concrete," Ultrasonics, vol. 73 , pp. 88-95, Jan. 2017.

[17] A. P. B. Capraro, C. B. Scremim, M. H. F. Medeiros, and N. S. Polegato, "Velocidade de Propagação de Ondas de 
Ultrassom e Resistividade Elétrica para a Detecção do Ataque por Sulfatos de Origem Interna.," vol. 2, no. 3, pp. 38-47, 2017.

[18] R. Demirboğa, İ. Türkmen, and M. B. Karakoç, "Relationship between ultrasonic velocity and compressive strength for high-volume mineral-admixtured concrete," Cem. Concr. Res., vol. 34, no. 12, pp. 2329-2336, Dec. 2004.

[19] N. Sabbağ and O. Uyanık, "Prediction of reinforced concrete strength by ultrasonic velocities," J. Appl. Geophys. vol. 141, pp. 13-23, Jun. 2017.

[20] M. G. HERNÁNDEZ, M. A. G. IZQUIERDO, A. IBÁÑEZ, J. J. ANAYA, and L. G. ULLATE, "Porosity estimation of concrete by ultrasonic NDE," Ultrasonics, vol. 38, no. 1-8, pp. 531-533, Mar. 2000.

[21] E. Mesquita, R. Martini, A. Alves, P. Antunes, and H. Varum, "Non-destructive characterization of ancient clay brick walls by indirect ultrasonic measurements," J. Build. Eng., vol. 19, pp. 172-180, Sep. 2018.

[22] E. Mesquita et al., Heterogeneity detection of Portuguese-Brazilian masonries through ultrasonic velocities measurements, vol. 8. 2018.

[23] ABNT - ASSOCIAÇÃO BRASILEIRA DE NORMAS TÉCNICAS, "NBR 5739 - Ensaio de compressao em corposde-prova cilindricos," Rio de Janeiro, 2007.

[24] ABNT - ASSOCIAÇÃO BRASILEIRA DE NORMAS TÉCNICAS, "NBR 5738: Concreto - Procedimento para moldagem e cura de corpos de prova," Rio de Janeiro/RJ, 2003.

[25] ABNT - ASSOCIAÇÃO BRASILEIRA DE NORMAS TÉCNICAS, "NBR 7211 - Agregados para concreto - especificação," Rio de Janeiro-RJ, 2009.

[26] J. F. Freire, D. J. Q. ROSA, R. G. V. CARVALHO, R. J. PEDROSA, J. M. A. PINTO, and O. L. NASCIMENTO, "Estudo do comportamento da velocidade de onda ultrassônica em concreto fresco de cimento Portland," in Anais do $58^{\circ}$ Congresso Brasileiro de Concreto - CBC 2016, 2016, no. 1.

[27] ABNT - ASSOCIAÇÃO BRASILEIRA DE NORMAS TÉCNICAS, "NBR 9779: Argamassa e concreto endurecidos - Determinação da absorção de água por capilaridade," Rio de Janeiro/RJ, 1995.

[28] ABNT - ASSOCIAÇÃO BRASILEIRA DE NORMAS TÉCNICAS, "NBR 7215: Cimento Portland - Determinação da resistência à compressão," Rio de Janeiro/RJ, 1996.

[29] V. M. . Malhotra and N. J. Carino, Handbook on Nondestructive Testing of Concrete, $2^{\text {a }}$ edition. New York: CRC Press, 2004.

[30] S. A. ABO-QUDAIS, "Effect of concrete mixing parameters on propagation of ultrasonic waves," Constr. Build. Mater., vol. 19, no. 4, pp. 257-263, 2005.

[31] L. M. DEL RÍO, A. JIMÉNEZ, F. LÓPEZ, F. J. ROSA, M. M. RUFO, and J. M. PANIAGUA, "Characterization and hardening of concrete with ultrasonic testing," Ultrasonics, vol. 42, no. 1-9, pp. 527-530, 2004.

[32] E. Ohdaira and N. Masuzawa, "Water content and its effect on ultrasound propagation in concrete - the possibility of NDE," Ultrasonics, vol. 38, no. 1-8, pp. 546-552, Mar. 2000. 